2. That the United States reexamine the reservations it has previously attached to human rights treaties, with a view to withdrawing those that are not constitutionally required.

3. That the United States abandon its practice of declaring human rights conventions non-self-executing. If a human rights convention has been declared nonself-executing, the United States should enact early legislation to implement the convention. In general, if U.S. ratification of a convention does not ipsi facto bring U.S. law and practice up to international human rights standards, the United States should enact legislation to achieve that end.

4. That the United States enter a new declaration under the optional clause of the Statute of the International Court of Justice that would not exclude disputes under the human rights conventions.

LOIJIS HENKIN

\title{
PRoteCTING INDIGENOUS RightS IN INTERNATIONAL ADJUDICATION
}

From the time that proto-human bands roamed the wilds, "within one of the most common geopolitical patterns in world history," organized peoples have invaded inhabited territories and tried to make themselves dominant. When they were successful, they developed elaborate religious, moral or legal systems that celebrated and validated their control. The "natives," "aborigines," or "indigenous peoples" were the ones who were there and lost; they either resisted, or were denied, assimilation and survived with a distinct, but not necessarily intact, cultural identity. The term "indigenous rights" has recently come to refer, within the larger system of the international protection of human rights, to a new pattern of claims, made by these surviving indigenous peoples, for direct protection by the international community and, where appropriate, restoration of rights taken from them in the past. Belatedly, indigenous peoples are clemanding a place in modern international law.

In the past, if the indigenous peoples survived disease, economic exploitation and sometimes genocide (and many did not), they were consigned to a kind of international legal shadow land. The international law of the newcomers allowed them the weakest of rights of title to the lands they inhabited ${ }^{2}$ and even weaker rights to equal treatment under the law. ${ }^{3}$ Their languages were not dignified as such; their law, if it was recog-

\footnotetext{
2 Donald W. Meinig, The Shaping of America: Continental America 1800-186" at 185 (1993).

2 See Mark F. Lindley, The ACQUisition and Government of BaCKWARd TERritory IN INTERnATIONAL. LAW 337-53 (1926).

3 The unequal application to foreigners of the act of state doctrine in Britain exemplifies this practice. Under British law, it was no defense to the commission of a wrongful act against the person or property of a British subject that the act was done at the behest of the Crown. Johnstone v. Pedlar, [1921] \% App. Cas. 262, 271 (appeal taken from Ir.). However, in the case of acts committed abroad against a foreigner being sued upon in British courts, the British tortfeasor could raise the defense that the act had been undertaken by the command of the British Government, or that the British Government had ratified the act after it had been committed. Successfully raising this defense divested British courts of jurisdiction over the case. Id. Accordingly, the Crown could retroactively immunize depredations abroad of British subjects against indigenous peoples. The Privy Council in Johnstone ameliorated the unfairness of the act of state doctrine by denying its applicability to wrongs committed against foreigners on British soil. Id. at 273.

Indigenous peoples and dominant ethnic groups in U.S. territories fared little better under U.S. law. At dispute in the Insular Cases, a series of Supreme Court decisions beginning with De Lima v. Bidwell, 182 U.S. 1 (1901), and ending with Balzac v. Porto Rico, 258 U.S. 298 (1922), was the legal status of newly acquired
} 
nized as law, was deemed "primitive," appropriate for study by anthropologists, rather than jurists; and their religions and mores were likely to be viewed as exotic or barbaric atavisms.

Some of the Spanish fathers tried to protect indigenous peoples through moral and legal theories deriving from natural law, ${ }^{4}$ but the theories were not translated into notable political success. By the nineteenth century, with the ascendance of the conception of positive international law as a corpus juris created through the will of states, indigenous peoples, who were not organized in states, all but disappeared from international law's construct of reality. In the Cayuga Indians case, ${ }^{5}$ a comparatively enlightened award, the tribunal said:

From the time of the discovery of America the Indian tribes have been treated as under the exclusive protection of the power which by discovery or conquest or cession held the land which they occupied... . The power which had sovereignty over the land has always been held the sole judge of its relations with the tribes within its domain. The rights in this respect acquired by discovery have been held exclusive. ${ }^{6}$

Of course, the notion of "exclusive national protection" means the denial of all international protection when the problem is deprivative national action.

overseas territories and the degree of constitutional protection to be extended to their inhabitants. In a famed concurrence, Justice White wrote that, although the Constitution applied to an unincorporated territory such as Puerto Rico, which Congress had not fully integrated into the United States, see Downes v. Bidwell, 182 U.S. 244, 292-93 (1901) (White, J., concurring), not every provision of the Constitution bound Congress in legislating for unincorporated territories, see id. at 340-42. Justice White justified denial of equal protection to the inhabitants of unincorporated territories on the grounds that those peoples might form "an uncivilized race. . . absolutely unfit" to receive American citizenship. Id. at 306. This line of thinking culminated in 1922 when Chief Justice Taft, finally speaking for a majority of the Court, adopted White's theory, in part because the residents of Puerto Rico-despite their American citizenship-were "of a different origin and language from those of our continental people," Balzac, 258 U.S. at 311 . For detailed analysis, see Gerald R. Neuman, I'losi Constitution?, 100 Y AL.E. L.J. 909, 957-64 (1991), on which this discussion draws. See also Frederic R. Coudert, The Ezolution of the Doctrine of Territorial Incorporation, 26 CoLUM. L. REV. 823 (1926) (reviewing Insular Cases).

${ }^{4}$ Sir, r.g., Bartolomé de las Casas, Brevísima relación de la destrucción de las Indias, in 10 Obras CoMPLETAS 29 (Ramón Hernández \& Lorenzo Galmés eds., 1992) (1537, pub. 1552), translated in The DeVASTATION OF THE INDIES: A BRIEF ACCOUNT (Herma Briffault trans., 1974); BARTOLOMÉ DE LAS CASAS, Histortu de las Indlas (André Niu Van ed., 1986) (1561), abridged and translated in HISTORY OF THE INDIES (Andrée Collard ed. \& trans., 1971); Alonso DE LA VERA CRUZ, De dominio infidelium et justo bello, in 2 THE Writings of Alonso de LA VERA CRUZ 91 (Ernest J. Burrus ed. \& trans., 1968) (1553-54); FrANCISCO DE VITORIA, De lindls recenter int' $n$ tis, in DE INDIS ET DE JURE BELLI RELECTIONES 217 (Ernest Nys ed. \& John P. Bate trans., Carnegie ed. 1917) (1532); idem, De jure belli Hispanorum in barbaros, in DE INDIS ET DEJURE BELLI RELECTIONES, supra, at 269 (1532). For a history of the Jesuit Republic in Paraguay, see PHILIP CARAMAN, THE Lost PaR Inise: AN Account of THE Jesuits in PARAguaY, 1607-1768 (1975).

${ }^{5}$ Cay'uga Indians (Gr. Brit.) v. United States, 6 R.I.A.A. 173 (U.S.-Brit. Arb. Trib. 1926). In Cayuga Indiaks, Great Britain brought a claim against the United States on behalf of the Cayuga Indians in Canada for payment of an annuity covenanted to be paid to the "Cayuga Nation" by the State of New York in a 1795 treaty. At the time of the treaty, the majority of the Cayuga had migrated to Canada. The State of New York paid the annuity to the Cayuga Nation according to the terms of the 1795 treaty until 1810 , when the Cayuga in Canada sided with the British in the War of 1812. Beginning in 1810, New York paid the annuity only to the Cayuga in New York. Id. at 175-76. The tribunal held that the Cayuga Nation and the Cayuga as individuals had no status under international law. $I d$. at 176 . Nevertheless, the tribunal ruled on strictly legal grounds that under Article IX of the Treaty of Ghent, in which the United States agreed to restore the Indians to their position prior to the War of 1812, the United States was liable for payment of the annuity to the Cayuga in Canada. Id. at 184-86. An award of $\$ 100,000$ in unpaid interest and for a capital sum whose interest would provide a one-half share of the annuity was given to the Canadian Cayuga. Id. at 189-90. Interestingly, the tribunal also noted that general principles of equity, fair dealing and justice recognized by international law established that the Cayuga in Canada ought to have been paid a proportionate share of the annuity from 1810 onwards and that the tribunal could have justified its award on that basis alone. Id. at $179-84$.

Id. at 176. 
I.

The moral imperative of the historic movement of decolonization is directly relevant to the claims of indigenous peoples. Decolonization was not the grievance of particular historical "sore losers." Those who demanded decolonization invoked what they took to be a basic legal and moral principle. They protested the very idea of the subjugation of one people by another and the imposition of an alien language and law, and they insisted on the right of all peoples to determine by whom and how they should be governed. In addition, the aspiring national elites who demanded decolonization promised the introduction of a genuine rule of law. Colonized peoples, painfully familiar with legal double standards, with courts that purported to be-but were not in fact-independent and impartial, with detentions without trial, and with police brutality, certainly knew that a meaningful system of law was the ultimate bulwark against tyrianny. Decolonization was really a demand for law and human rights. ${ }^{7}$

Despite the moral relevance of decolonization to the situation of indigenous peoples, decolonization rarely encompassed indigenous peoples. In the New World, decolonization benefited mostly so-called Creole or local elites of European extraction. Legal doctrines such as uti possidetis juris, which the elites of the new states appropriated in the nineteenth century, effectively precluded any recognition of rights to the lands that indigenous peoples had historically inhabited. Uti possidetis juris was a Latin neologism (and, at that, an inversion of the Praetorian edict whose terms it purloined so as to give itself the illusion of the authority of antiquity); ${ }^{8}$ it bestowed an aura of historical legality to the expropriation of the lands of indigenous peoples. The new elites divided territory among themselves exactly as had the former imperial powers-in other words, without regard to the claims or interests of the aboriginal inhabitants. ${ }^{9}$

Even when the United Nations began to legislate for the rights of peoples, the elites of those same states established the rules of the game. Not surprisingly, restrictive definitions and complex interstate procedures for determining who was a people generally ensured that indigenous peoples would not qualify. The most dramatic example is to be found in the illumination, by the UN General Assembly, of Resolutions 1514 (XV) and 1541 (XV) on the Granting of Independence to Colonial Countries and Peoples of 1960. Principle IV of the annex to Resolution 1541 (XV), setting out "[p]rinciples which should guide Members in determining whether or not an obligation exists to

\footnotetext{
${ }^{7}$ For an eloquent elaboration of this point, see Shri Virendra Dayal, Patriotism and Human Rights, Lecture at the Sardar Vallabhbhai Patel National Police Academy, Hyderabad, India (Mar. 22, 199.4) (transcript on file with author); see also MYRes S. MCDOUgal, HAROLD D. LASSWELl \& LUNG-CHU CHEN, HuMAN Rights AND WORLD PUBLIC ORDER 114 n.44 (1980) (linking decolonization with demands by deprived peoples for wider participation in shaping and sharing global values, including human rights).

${ }^{8}$ Ironically, the Praetorian edict uti possidetis iti possideatis (literally, "as you possess, so may you possess") was an effective occupative concept that, applied in its original sense, would have benefited the indigenous peoples. The edict was shorthand for the Latin interdict "Uti nunc eas aedes, quibus de agitur, nec vi nec clam nec precario alter ab altero possidetis, quo minus ita possideatis, vim fieri veto." JOHN B. MOORE, MEMORANDUM ON UTI POSSIDETIS: Costa RICA-PANAMA ARBITRATION 6 (1913), reprinted in 3 THE Col. LECTED PAPERS OF JOHN BASSETT MOORE 328, 329 (John Bassett Moore Fund 1944). Under this interdict, "the possession was adjudged to the actual possessor unless he had obtained it vi clam or precerio [literally, "by force, in secret, or with permission'] from the other, in which case it was given to that other." WILLIAM W. BUCKLAND, A TEXTBOoK of Roman LAW From Augustus to Justinian 734 (Peter Stein ed., 3d rev. ed. 1963); see also FriTz SCHULz, ClASSICAL ROMAN LAW 60, 448-53 (1951) (explaining that uti possidetis was almost always used to confirm possession of property by open, peaceful occupant). Such an interdict confirming the rights of the occupant would clearly have been favorable to indigenous land rights, if properly applied.

${ }^{9}$ For an analysis of the transformation of the classical Roman concept of uti possidetis, which confirmed possession of land by a peaceful occupant, into a principle of international law, used by Latin American states in boundary disputes, that vested definitive title in conquered or discovered lands to the conquering or discovering occupants and their successors, see MOORE, MEMORANDUM ON UTI POSSIDETIS, supra note 9, at $5-45$.
} 
transmit the information called for in Article 73 of the Charter of the United Nations," states: "Prima facie there is an obligation to transmit information in respect of a territory which is geographically separate and is distinct ethnically and/or culturally from the country administering it." 10 The cumulative requirement of ethnic distinctiveness and geographical separateness effectively excludes most indigenous peoples.

Despite this history of nonrecognition, the rights of indigenous peoples are belatedly being recognized, for human rights is a dialectical process that brings to popular consciousness the plight of individuals and groups that have been pushed to the margins of the legal system and deprived of the basic rights of human dignity. Nongovernmental organizations are championing their cause, ${ }^{11}$ and draft declarations are being prepared at the international and regional levels. ${ }^{12}$ Most importantly, the leaders of many of the indigenous groups are learning to use the rules of the game and so are somewhat better able to protect the interests of their peoples. The Vienna Declaration and Programme of Action adopted by the World Conference on Human Rights in June 1993 recommended that the UN General Assembly proclaim an international decade of the world's indigenous peoples, to begin in January $1994 .{ }^{13}$ In its Resolution $48 / 163$ of December 21,1993 , the General Assembly proclaimed that the decade would commence on December 10,1994 , with the objective of "strengthening ... international cooperation for the solution of problems faced by indigenous people in such areas as human rights, the environment, development, education, and health."14

The claims of indigenous peoples have implications, as yet only dimly appreciated, for many relatively settled sectors of modern international law. But the process of actualization is slow, and the often "soft" changes in one part of the international corpus juris are only slowly carried over into others. As a result, many anachronisms survive; some continue to be applied as law, perpetuating the injuries of a historical era now condemned and lamented.

\footnotetext{
${ }^{10}$ UN Dep'T OF Pol. AfF., Decolonization, Dec. 1975, at 54. Article 73 of the UN Charter requires states that administer non-self-governing territories "to transmit regularly to the Secretary-General for information purposes, subject to such limitation as security and constitutional considerations may require, statistical and other information of a technical nature relating to economic, social, and educational conditions in the territories for which they are respectively responsible."

${ }^{11}$ The literature by nongovernmental organizations decrying the denial of basic rights to indigenous peoples has exploded over the past 10 years, both in quantity and in the number of organizations represented. $S e, \cdot g$, AMinesty International, Human Rights Violations Against Indigenous Peoples of the Americas (1992); Julian Berger, ABorigines TOday: LAND AND Justice (1988) (Anti-Slavery Society); Shelton H. Davis, LAND Rights and Indigenous Peoples: THe Role of THE INTER-AMERICAN ComMISSION ON HUMAN RightS (1988) (Cultural Survival); INDEPENDENT COMMISSION ON INTERNATIONAL HuMANITARIAN IsSUEs, INDIGENOUS PEOPLES: A GLOBAL QUEST FOR JUSTICE (1987); INDIGENOUS AFFAIRS (Serial 1994) (International Work Group for Indigenous Affairs); THE LAW OF THE MOTHER: PROtecting Indigenous Peoples in Protected AREas (Elizabeth Kemp ed., 1993) (World Wide Fund for Nature; International Union for the Conservation of Nature); JUAN E. MENDEZ, THE MisKITOS IN NICARAguA, I981-1984 (1984) (Americas Watch); Carole Nagengast, Human Rights and Indigenous WORKERS: THE MIXTECS OF MEXICO AND THE UNITED STATES (1992) (Center for U.S.-Mexican Studies); THE RIGHTS OF INDIGENOUS PEOPLES IN INTERNATIONAL LAW: WORKSHOP REPORT (Ruth Thompson ed., 1986) (University of Saskatchewan Native Law Centre).

${ }^{12}$ Set, e.g., Draft Declaration on the Rights of Indigenous Peoples as Agreed Upon by the Members of the Working Group at its Eleventh Session, UN ESCOR, Comm'n on Hum. Rts., Sub-Comm'n on Prevention of Discrimination and Protection of Minorities, 45th Sess., Ann. 1, Agenda Item 14, UN Doc. E/CN.4/Sub.2/ 1993/29 (1993); Draft Instrument on the Rights of Indigenous Peoples, Organization of American States (Aug. 8, 1994) (on file with author).

${ }_{13}$ Vienna Declaration and Programme of Action, UN GAOR, World Conference on Human Rights, 48th Sess., pt. II, para. 32, UN Doc. A/CONF.157/24 (Part I) (1993), reprinted in 32 ILM 1661, 1677 (1993).

${ }^{14}$ GA Res. 163, UN GAOR, 48th Sess., Supp. No. 49, at 281, UN Doc. A/48/49 (1993). For UN Secretariat proposals for this decade, see Programme of Action for the International Decade, Working Paper submitted by the Secretariat, UN Doc. E/CN.4/1994/AC.4/TM.4/3 (1994), and Programme of Activities of the International Decade of the World's Indigenous People, UN Doc. A/49/446 (1994). But, for an indication of the disappointment expressed by indigenous leaders about the lack of resources made available, see id. at 17, para. 77.
} 
II.

One such anachronism can be found in contemporary international adjudication, where the rights of indigenous peoples still fail to be recognized. When states adjudicate a territorial matter that may also concern the rights of indigenous peoples, the tribunals concerned generally ignore those rights. The tribunals address only the issues raised by the formal parties before them, which, under the rules of the game established by states, can only be states. ${ }^{15}$ With the exception of the Cayuga Indians case ${ }^{16}$ indigenous peoples are still essentially invisible or, if noticed, treated, legally, along with the flora and fauna of the land concerned.

In Cayuga Indians, the tribunal acknowledged that the rights of a tribe could not have been protected by that tribe during the long period in which it was subjuggated, for it had no international standing. Hence, the tribunal concluded that those rights were not blocked by an estoppel or a laches. ${ }^{17}$ That rather modest démarche may mark the high point of international adjudication's contribution to the plight of indigenous peoples.

Judges of the International Court of Justice have indicated that they appreciate that this is a sensitive issue. They have often said some of the politically correct things, but the Court has carefully avoided giving any meaningful legal effect to territorial claims based on indigenous theories of law. For example, in the Western Sahara case, ${ }^{18}$ the Court formally acknowledged the existence of a theory of international land tenure based on a non-European conception of title as generative of "legal ties"19 (whatever that means). But such "legal ties" were not enough to defeat title deriving; from a European colonial claim. In that case, Morocco and Mauritania had claimed title to parts of territory in Western Sahara based on non-European theories and practices of governance. Morocco, for example, claimed that it had exercised authority as the "Sherifian State." 20 The Court acknowledged:

That the Sherifian State at the time of the Spanish colonization of Western Sahara was a State of a special character is certain. Its special character consisted in the fact that it was founded on the common religious bond of Islam existing among the peoples and on the allegiance of various tribes to the Sultan, through their caids or sheikhs, rather than on the notion of territory. ${ }^{21}$

Nevertheless, the Court still applied the European notion of acquisition of title as the exclusive criterion:

Political ties of allegiance to a ruler, on the other hand, have frequently formed a major element in the composition of a State. Such an allegiance, however, if it is to afford indications of the ruler's sovereignty, must clearly be real and manifested in acts evidencing acceptance of his political authority. Otherwise, there will be no genuine display or exercise of State authority. ${ }^{22}$

By insisting on the application of the Western concept, the potential legal force of the indigenous form of political organization was drained.

\footnotetext{
${ }^{15}$ For a discussion of the extent to which the International Court of Justice limits itself to addressing only issues raised by the formal parties versus the likelihood of its deciding cases on issues raised proprio motu, see Carsten Smith, The Relation Between Proceedings and Premises (1962).

${ }^{16}$ Cayuga Indians, 6 R.I.A.A. 173 (1926). $\quad{ }^{17}$ Id. at 189.

${ }^{18}$ Western Sahara, 1975 ICJ REP. 12 (Advisory Opinion of Oct. 16). The Court heard this case at the request of the UN General Assembly.

${ }^{19}$ Id. at 64-65, 68. See generally id. at 40-68 (analyzing nature of legal ties between Western Sahara and Kingdom of Morocco and Mauritanian entity). It seems to be unwise, on policy grounds, to create "half" titles that are not enough to win a case, but sustain national aspirations. For territorial claims, which are by their nature exclusively disjunctive, the better rule is clean decisions that leave no ends hanging.

${ }^{20}$ Id. at $43-44$.

${ }^{22} I d$.

${ }^{21}$ Id. at 44 (emphasis added).
} 
Similarly, in its treatment of the Mauritanian claim, the Court gave with one hand while taking back with the other:

The information before the Court makes it clear that the nomadism of the great majority of the peoples of Western Sahara at the time of its colonization gave rise to certain ties of a legal character between the tribes of the territory and those of neighbouring regions of the Bilad Shinguitti [the land of the Shinguitti]. The migration routes of almost all the nomadic tribes of Western Sahara ... crossed what were to become the colonial frontiers and traversed, inter alia, substantial areas of what is today the territory of the Islamic Republic of Mauritania. The tribes, in their migrations, had grazing pastures, cultivated lands, and wells or water-holes in both territories, and their burial grounds in one or other territory. These basic elements of the nomads' way of life ... were in some measure the subject of tribal rights, and their use was in general regulated by customs. Furthermore, the relations between all the tribes of the region in such matters as intertribal clashes and the settlement of disputes were also governed by a body of intertribal custom. Before the time of Western Sahara's colonization by Spain, those legal ties neither had nor could have any other source than the usages of the tribes themselves or Koranic law. Accordingly, although the Bilad Shinguitti has not been shown to have existed as a legal entity, the nomadic peoples of the Shinguitti country should, in the view of the Court, be considered as having in the relevant period possessed rights, including some rights relating to the lands through which they migrated. ${ }^{23}$

Consequently, the Court concluded that these rights constituted "legal ties" between the territory of Western Sahara and the "Mauritanian entity," that is, the tribes living in the territories of the Bilad Shinguitti that were then within the Islamic Republic of Mauritania. "They were ties which knew no frontier between the territories and were vital to the very maintenance of life in the region." ${ }^{24}$ Nevertheless, despite finding that there were "legal ties of allegiance" and "some rights relating to the land," the Court saw "nothing to establish any tie of territorial sovereignty between the territory of Western Sahara and the Kingdom of Morocco or the Mauritanian entity."

In the Gulf of Fonseca Judgment ${ }^{26}$ of a chamber of the International Court, the dismissal of indigenous claims was quite astonishing, as the submission agreement for that case contained language that plainly invited their examination. In part of the pleadings on the land boundary sections of the Gulf of Fonseca case, El Salvador drew the Chamber's attention to the potential conflict between claims based on Spanish documents and those on earlier rights of "Indian poblaciones."27 Article 5 of the Special Agreement that submitted the case to the Chamber provided:

In accordance with the provisions of the first paragraph of Article 38 of the Statute of the International Court of Justice, the Chamber, when delivering its Judgment, will take into account the rules of international law applicable between the Parties, including, where pertinent, the provisions of the General Treaty of Peace. ${ }^{28}$

${ }^{25}$ Id. at 68 . In a separate opinion, Judge Dillard argued for a more functional, transcultural test, based not on observable signs of sovereignty, but on "the consciousness of the people." Id. at 125 (Dillard, J., sep. op.).

${ }^{26}$ Land, Island and Maritime Frontier Dispute (El Sal. v. Hond., Nicar. intervening), 1992 ICJ REP. 351 (Sept. 11), ataalable in 1992 WL 457492 [hereinafter Gulf of Fonseca]. Gulf of Fonseca involved a dispute over (1) six land boundary lines between El Salvador and Honduras that had been left unsettled by the 1980 peace treaty ending the so-called Soccer War of 1969; (2) sovereignty over islands in the Gulf of Fonseca; and (3) the legal status of the maritime spaces in the gulf. The Court permitted Nicaragua to intervene to a limited degree respecting the legal status of the waters in the gulf.

27 S $t^{\prime}$ id., paras. 49, 51, 1992 WL 457492, at *93-95, 96-97.

${ }^{28} I d$., para. 3, 1992 WL 457492 , at * I7. 


\section{Article 26 of the General Treaty of Peace of 1980 provided:}

For the delimitation of the frontier line in areas subject to controversy, the Joint Frontier Commission shall take as a basis the documents which were issued by the Spanish Crown or by any other Spanish authority, whether secular or ecclesiastical, during the colonial period, and which indicate the jurisdictions or limits of territories or settlements [poblaciones]. It shall also take account of other evidence and arguments of a legal, historical, human or any other kind, brought before it by the Parties and admitted under international law. ${ }^{29}$

El Salvador drew attention to the word "poblaciones" in Article 26 and argued:

To determine the limits between the municipal territories of these Indian "poblaciones" or settlements and not between ancient Spanish provinces or the limits of private land properties, is what has been agreed in Article 26, as the method to be applied in order to implement in this case the principle of uti possidetis juris. And this may be done only on the basis of the títulos ejidales invoked by $\mathrm{El}$ Salvador. ${ }^{30}$

The Chamber rejected this contention.

If El Salvador is arguing that the Parties have by treaty adopted a special rule or method of determination of the uti possidetis juris boundaries, for the purposes of the present dispute, the Chamber is not persuaded by this contention. It was the administrative boundaries between the Spanish colonial administrative units, not the boundaries between the Indian settlements as such, that were transformed by the operation of the uti possidetis juris, into international boundaries in 1821 . The Chamber is unable to read the text of the General Treaty of Peace as coritemplating that the international boundaries should instead follow the limits of poblaciones. ${ }^{31}$

Hence, a juridical value for indigenous rights was denied, even in a case where the parties had authorized the Court to take account of them.

The same pattern of devaluation of indigenous claims was replicated by the International Court of Justice in the recent Territorial Dispute case ${ }^{32}$ between Libya and Chad. That dispute concerned a tract of territory believed to contain uranium deposits ${ }^{\mathbf{3 3}}$ over which neither the current claimants nor the predecessor colonial powers had exercised effective occupation. The area is not, however, "a land without a people." It has been populated by the Toubou, a people divided into clans, who have lived in the area, literally, from the time whence the memory of man runneth not. ${ }^{34}$

The Court, having expressed the now-standard laments over the insensitivity of colonial boundary making, asked for no evidence on the identity, interests and wishes of the inhabitants. It decided the issue entirely on the basis of a submission by the two claimant states. Each, pressing its own claims to the resources of the area, had no interest in allowing a possible outcome of terra nullius, even less in examining the interests or claims

${ }^{29}$ Id., para. $47,1992 \mathrm{WL} 457492$, at $* 92$.

${ }^{30}$ Id., para. 49, 1992 WL 457492 , at *94.

${ }^{91}$ Id., para. 50, 1992 WL 457492, at *95-96. Judge ad hoc Torres-Bernárdez's separate opinion even more emphatically denied that limits of indigenous poblaciones constituted a rule of law for settling the boundary. See 1992 ICJ REP. at 644-49, paras. 28-37, 1992 WL 457492, at *529-39.

${ }_{32}$ Territorial Dispute (Libya v. Chad), 1994 ICJ REP. 6 (Feb. 3), reprinted in 33 ILM 571 (1994). Libya and Chad submitted to the Court a longstanding dispute over territorial claims in their border region, including the Aouzou strip. The Court awarded virtually all of the disputed territory to Chad, in accordance with the latter's submission.

${ }^{33}$ Henry W. Dagenhardt, Chad-Libja, in Border ANd Territorial. Disputes 113, 114 (Alan J. Day ed., 2d ed. 1987).

${ }^{34}$ Matthew M. Ricciardi, Title to the Aouzou Strip: A Legal and Historical Analysis, 17 YALE J. INT"L L. 301, 313-14 (1992). Ricciardi's brilliant and comprehensive study lapses into a legal anachronism in assessing title claims of the Toubou, for he uses Western categories of title, under which the claims of she indigenous inhabitants fail. See id. at 382-434, 468-69. For further discussion, see infra part III. 
of the local inhabitants. ${ }^{35}$ What is particularly striking in this case is that the Court virtually acknowledged that no one but the indigenous inhabitants had the degree of contextually relevant effective occupation that is required by international law. Nevertheless, in the last paragraph of the Judgment, the Court capped its approach by stating that "the effectiveness of occupation of the relevant areas in the past, and the question whether it was constant, peaceful and acknowledged, are not matters for determination in this case."36 What was to be applied to the relations of now-independent states in Africa was a documentary world and, ironically, one produced by the same former colonial powers whose insensitive boundary making all good people now lament. ${ }^{37}$

Judge Shahabuddeen's separate opinion captures the essence of this odd, almost eerie, personal detachment and disengagement of judicial responsibility, not from past tragedies that may be irreparable, but from the contemporary, continuing tragedy of indigenous peoples caused by the inertial, and apparently unthinking, application of anachronistic law. Judge Shahabuddeen wrote:

The case at bar recalls a world now left behind. In telling flashes, it illuminates an age when international law tended to develop as a legal construct supportive of the global projection of the power of a single region; when in important respects it was both fashioned and administered by leading members of a select community; when that community, by itself called the international community, bore little resemblance to the world as it then stood, and even less to the world as it stands today. ... Both Parties, however, correctly accepted that the legal manners of the times were not on trial. Thus, if it were necessary to examine some of the issues bequeathed by the past to the present, it is possible that it is the law as it then was which would still govern.

As it has turned out, there is no need to do so. ${ }^{38}$

There was no need to do so, because the Court was content to accept the premise of the case that the two Governments, pressing the claims of their colonial predecessors, found to be in their common, though competitive, interest: that the land had to belong to one or the other of them, but to no one else, and certainly not to the inhabitants.

\section{III.}

The substantive issues that an indigenous rights claim would raise if it could be presented in an international adjudication will depend, in each case, on the nature of the formal dispute before the Court and the idiosyncratic history of relations between various colonizing forces and the indigenous peoples. In boundary and territorial title disputes, the indigenous claim is not necessarily one for self-determination. In Gulf of Fonseca, the parties to the dispute had indicated to the Court a choice-of-law rule, viz., that the consideration of the parties' competing claims of title should, where appropriate,

\footnotetext{
${ }^{35} S_{e}$ Territorial Dispute, 1994 ICJ REP. at 12-14, 15. In its submission, Libya argued "that the territory in question, at all relevant times, was not terra nullius," $i d$. at I3, and that the "indigenous peoples were, at all relevant times, religiously, culturally, economically and politically part of the Libyan peoples," $i d$. Libya based its claim, as a state, in part on the rights and titles conferred by indigenous inhabitants. Id. at 15 .

${ }^{36} I d$, at 38 .

${ }^{37}$ Not surprisingly, the agreement between the parties to implement the Judgment includes. language that would continue to block claims of indigenous peoples. Article 5, paragraph I states: "With a view to ensuring their joint security, the two Parties shall refrain from encouraging or providing any support whatsoever from their territories to groups hostile to either of the Parties." Agreement between the Great Socialist People's Libyan Arab Jamahiriya and the Republic of Chad concerning the practical modalities for the implementation of the Judgment delivered by the International Court of Justice on 3 February 1994, Apr. 4, 1994, UN Doc. S/1994/402, Annex (1994), reprinted in 33 ILM 619,621 (1994).

${ }^{38}$ Territorial Dispute, 1994 ICJ REP. at 44 (Shahabuddeen, J., sep. op.), available in 1994 WL 417031, at $* 69$.
} 
be traced through indigenous claims. In effect, the parties had selected indigenous law as the law that might have governed the acquisition or retention of title in one of the temporal links through which international title must be traced. In this case, resort to indigenous legal systems and the rights that they may have established or affirmed in periods when they were in force would have involved no jurisdictional initiative by the Court. On the contrary, the Court had been instructed to undertake this inquiry by the parties themselves. ${ }^{39}$

In many other cases, however, the law of indigenous populations will not have been designated by the parties as one choice of law. In these circumstances, the challenge to the Court will be more formidable. Suppose, for example, that a boundary dispute is before the Court and independent investigation indicates that over a long period of time indigenous inhabitants, taking account of the ecology, have established patterns of migration across the border. ${ }^{40}$ In that case, the Court, on its own initiative, should confirm that the rights of the indigenous peoples "run with the land," as it were, and state explicitly in the judgment that whichever state party that ultimately prevails in the boundary or territorial claim must give effect, by virtue of international law, to these customary rights. The heuristic for this sort of investigation may be found in the Right of Passage case. ${ }^{41}$

Thus, the Court can, by declaration, confirm the existence of customary rights deriving from indigenous law that must be recognized by the states parties. Where indigenous peoples have established a pattern of habitation that depends on access to certain resources, the assignment by the Court of the territory to one of the claimant states should indicate that, as a matter of international law, the prevailing state must give effect to these indigenous rights, in what amounts to a servitude jure gentium.

If potential or latent indigenous claims must be raised and examined sua sponte by the Court, in cases where they have been ignored in submission agreements arid pleadings by the litigating states, it is because such claims raise issues of international law that the Court cannot itself ignore: curia novit lex. But this does not mean that indigenous claims

\footnotetext{
${ }^{39}$ See supra text at and notes $26-31$.

${ }^{40}$ Such a situation obtained in the Ogaden region of Ethiopia along the Ethiopian-Somali border. An 1897 treaty between Britain and Ethiopia gave the Ogaden to Ethiopia, but Annex 3 of the treaty reserved grazing rights for tribes from either side of the border in the Ogaden. Roger East, Ethiopia-Somalia, in BORDER AND TERRITORIAL DisPUTES, supra note 33, at 126, 126-28. Britain retained administration over the Ogaden under a 1944 treaty between the countries, Agreement for the Regulation of Mutual Relations, Dec. 19, 1944, UK-Eth., Art. VII, 93 UNTS 303, which was withdrawn by treaty in 1954, although tribal grazing rights were reaffirmed, Agreement Respecting the Withdrawal of British Military Administration from the Territories Designated as the Reserved Area and the Ogaden, Nov. 29, 1954, UK-Eth., Arts. I-11, 207 UNTS 284. See generally I. M. LEWIS, A MODERN History Of SOMAlia: NATION ANd STATE IN THE HORN OF AFRICA (rev. ed., Longman 1980) (1965).

${ }^{41}$ Right of Passage over Indian Territory (Port. v. India), 1960 ICJ REP. 6 (Apr. 12). Portugal petitioned the Court to declare that Portugal held, inter alia, rights of passage between the territory of Damão, on the northeastern coast of India north of Bombay, and its territorial enclaves of Dadrá and Nagar-Aveli, and between the enclaves themselves, to the extent required for the effective exercise of Portuguese sovercignty over the territories. $I d$. at 9-10. In mid-1954, Portuguese authority in Dadrá and Nagar-Aveli had been overthrown with the assistance of groups based in Indian territory. Id. at 30 . India subsequently suspended Portuguese passage through Indian territory to the enclaves, $i d$. at 44 , and Portugal asked that the Court declare that the suspension violated India's international obligations arising from custom and treaties, $i d$. at 9 .

After examining the history of local practice regarding the contested right, the Court held that local custom during the British and post-British periods established Portugal's right of passage for private persons, civil officials and goods, subject to India's regulation. Id. at 40 . However, the Court also ruled that no right of passage existed for armed forces, armed police, and arms and ammunition, since local custom gave British and Indian authorities discretion to deny passage for those items. Id. at 43 .

It is this investigation of customary rights, see $i d$. at $35-43$, that are recognized by international law in $R$ ight of Passage that could serve as a model for the treatment by international tribunals of the rights of indigenous persons.
} 
should always prevail. The Court must also test the indigenous claims against peremptory norms of international law and, in particular, against those internationally protected human rights that have entered into contemporary international law. Some indigenous claims will surely fail that test and must be rejected. ${ }^{42}$

The critical point is that, as a substantive matter, the Court should not ignore indigenous rights and transfer title or confirm possession by a state as if the territories involved were vacant. To do this simply reenacts the tragedy of colonialism.

\section{IV.}

Aside from substantive law, the Court can take various procedural steps to respond to the anachronistic treatment of indigenous peoples' rights.

First, the International Court should not apply the terms of reference the parties submit to it without regard to the compatibility of those terms of reference with international law itself. As the late Judge Lachs said, in a different but still pertinent context, "the Court is the guardian of legality for the international community as a whole, both within and without the United Nations."43 States that conclude special agreements plainly prefer a compromis that does not allow third parties to challenge them. Precisely because there are limited rights of intervention in the procedure of the Court, ${ }^{44}$ the Court must examine the premises that the parties consciously or unconsciously postulate for their compatibility with general international law. The Court cannot simply accept those premises. In international adjudication, the basis of jurisdiction is a "submission" and not an acte de mandat.

This process will require careful reconsideration of certain practices in the past. Until now, the Court has generally accepted the postulates that the parties have fixed, without examining their compatibility with general international law. ${ }^{45}$ This acceptance involves a confusion between matters of "jurisdiction"- - the capacity to adjudicate with regard to particular states and on particular issues - which, indeed, is based on consent, and matters of "competence" - the statutorily determined procedures that the Court

\footnotetext{
${ }^{12}$ St' generally W. Michael Reisman, Autonomy, Interdependence, and Responsibility, 103 YALE L.J. 401 (1993).

${ }^{43}$ Questions of Interpretation and Application of the 1971 Montreal Convention Arising from the Aerial Incident at Lockerbie (Libya v. U.S.), Provisional Measures, 1992 ICJ REP. 114, 138 (Order of Apr. 14) (Lachs, J., sep. op.) [hereinafter 1971 Montreal Convention]. Libya sought, inter alia, a declaration by the Court that the United States should pursue arbitration under Article 14 of the 1971 Montreal Convention, a treaty governing terrorist acts against civil aviation. The Court held that UN Security Council Resolution 748 of March 31 , 1992, under chapter VII of the UN Charter, mandating Libyan cooperation with French, British and American attempts to bring to justice the Libyan official allegedly responsible for the bombing of Pan Am Flight 103 over Lockerbie, Scotland, divested the Court of jurisdiction in the matter. Judge Lachs's separate opinion emphasized that there was not, in the UN system, a complete separation of powers among the Security Council, the General Assembly, and the International Court of Justice; rather, the Court's deferral to a Security Council decision reflected the limits of the system within which the Court rendered justice. Ste id. at 138-39.

${ }^{14}$ ICJ STATUTE Art. 62, reprinted in 1978 ICJ, Acts \& Docs. 85 (giving Court discretion to accept requests to intervene); id. Art. 63, 1978 ICJ Acts \& Docs. 85 (giving states right to intervene where construction of convention to which state is party is involved); Rules of the Court, Arts. 81-86, 1978 ICJ Acts \& Docs. 14549 (establishing procedures for permissive intervention and intervention as of right). Cf. FED. R. CIV. P. 24 (conferring broad power on parties for intervention of right and on federal courts for permissive intervention). See generally SHABTAI RosenNe, INTERvention IN THE INTERnATIONAL COURT OF JuSTICE (1993).

${ }^{4}$ Set, e.g., Minquiers and Ecrehos case (Fr. v. UK), 1953 ICJ REP. 47, 49 (Nov. 17) (reprinting and applying special agreement between parties without examining its compatibility with international law). $C f$. Continental Shelf (Tunis. v. Libya), 1982 ICJ REP. 18, 37-38 (Feb. 24) (questioning propriety of applying to dispute, as specified in first paragraph of special agreement between parties, "new accepted trends" embodied in thenunfinalized United Nations Convention on the Law of the Sea); id. at 144-58 (Oda, J., dissenting) (disputing deference given by Court to draft Law of Sea Convention and contesting Court's reading of special agreement); SMITH, supra note 15, at 92-93 (arguing that parties cannot, by special agreement, compel Court to render judgment contrary to basic principles of international law).
} 
must follow in every case. Jurisdiction is determined by the parties. ${ }^{46}$ The Court's competence is determined by the Statute. It is inconceivable that the Court could adjudicate on the basis of premises, established by the parties in a compromis, that were inconsistent with Article 38 , the Court's statutory choice-of-law clause. ${ }^{47}$ Parties may prescribe a lex specialis before the Court that is infra or praeter legem, but not contra legem.

The problem is aggravated by the Court's passive application of the curia novit lex rule. ${ }^{48}$ In one of the last opinions he penned, Judge Lachs spoke of the Court's "vocation of applying international law as a universal law." 49 If the Court allows the states parties to territorial disputes to determine entirely on their own how the dispute will be structured, the interests of the continuing victims of the imperial and colonial era will never be recognized and protected.

As a second procedural step, the Court should be careful to apply international law in its contemporary acceptance. In earlier cases, the Court has remarked on the need for actualization as a mode of interpretation. ${ }^{50}$ Actualizing or contemporizing involves reading contemporary values into older provisions. The Court correctly perceives one of its functions as integrating older legal formulations into contemporary normative expectations and demands. Were the Court not to actualize, the result of its contemporary decisions would be the production of anachronism.

When presented with a submission that designates a putative rule of law as the one selected by the parties to govern the resolution of the dispute, the Court must check the compatibility of that doctrine with contemporary international law. Thus, when presented with the doctrine of uti possidetis juris in a submission or pleadings, a comprehensive legal view must be taken. In the frontier dispute between Burkina Faso and Mali, ${ }^{51}$ a chamber of the Court relied heavily on a resolution adopted at the first session of the Conference of African Heads of State and Government in Cairo in 1964, which

\footnotetext{
${ }^{46}$ There are exceptions. For example, the Security Council may determine the existence of $a$ threat to the peace under Article 39 of the UN Charter and then, acting under Articles 41 and 48 of chapter VII, order the parties to submit their dispute to the Court. By virtue of Articles 25 and 103, such a Security Council decision would then constitute a type of submission. See UN CHARTER Arts. 25, 39, 41, 48, 103. Cf. Corfu Channel case (UK v. Alb.), Preliminary Objection, 1948 ICJ REP. 15 (Mar. 25). British ships had suffered damage from mines placed in the Corfu Channel off the Albanian coast. The Security Council passed a resolution, SC Res. 22, UN Doc. S/INF/2/REV.1 (II), at 3 (1947), recommending that Britain and Albania refer the dispute to the Court. Albania indicated in a letter to the Court of July 2, 1947, that it was "prepared ... to appear before the Court," 1948 ICJ REP. at 20, despite the unilateral nature of Britain's Application and Albania's nonmembership in the United Nations. Albania argued that the Court did not have jurisdiction, since Albania, as a UN nonmember, could not be bound by Britain's unilateral Application absent the conclusion of a special agreement between the parties. Id. at 21. Albania also argued that the Security Council's recommending resolution did not confer jurisdiction over the dispute on the Court. Id. at 22 . The Court held, however, that it had jurisdiction, interpreting Albania's letter as waiving its right to conte.st the admissibility of the UK application. Id. at 26-27. One may question whether such intiatives will actually increase the Court's jurisdiction. See W. Michael Reisman, The Other Shoe Falls: The Future of Article 36(1) Jurisdiction in the Light of Nicaragua, 81 AJIL 166 (1987).

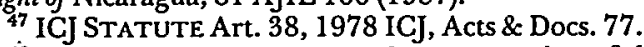

${ }^{48}$ Application for Revision and Interpretation of the Judgment of 24 February 1982 in the Continental Shelf (Tunisia/Libyan Arab Jamahiriya) (Tunis. v. Libya), 1985 ICJ REP. 192 (Dec. 10). The Court refused to revise its 1982 delimitation of the continental shelf between Libya and Tunisia, 1982 ICJ Rr.P. 18, despite the subsequent revelation that Libya had introduced misleading evidence about the western limit of its historic claims to the continental shelf area in dispute. Instead of acknowledging that its Judgment had proved to be erroneous, the Court refused Tunisia's request for revision because it found that Tunisia was negligently ignorant of the facts withheld by Libya. 1985 ICJ REP. at 206, paras. 26-28.

${ }_{49} 1971$ Montreal Convention, 1992 ICJ REP. at 138 (Lachs, J., sep. op.); see also supra note 43 (explaining

Judge Lachs's views).
50 See, e.g., South-West Africa-Voting Procedure, 1955 ICJ ReP. 67, 77 (Advisory Opinion of June 7). See generally MYRES S. MCDOUGAL, HAROLd D. LASSWELl \& JAMES C. MILLER, THE INTERPRETATION OF AGREEMENTS AND WORLD Public ORDER: Principles OF CONTEXT AND PROCEDURe 119-269 (1967).

${ }^{51}$ Frontier Dispute (Burk. Faso v. Mali), 1986 ICJ REP. 554 (Dec. 22) (fixing, accordıng to special agreement, border between parties along northernmost frontier of Burkina Faso with Mali).
} 
stated that all the member states of the Organization of African Unity "solemnly ... pledge themselves to respect the frontiers existing on their achievement of national independence." 52 The parties' special agreement had instructed the Chamber to reach a decision "based in particular on respect for the principle of the intangibility of frontiers inherited from colonization." 53 The Chamber endorsed uti possidetis juris as a "general principle, which is logically connected with the phenomenon of the obtaining of independence, wherever it occurs. Its obvious purpose is to prevent the independence and stability of new States being endangered by fratricidal struggles provoked by the challenging of frontiers following the withdrawal of the administering power." Chamber further asserted that "[ $u] t i$ possidetis, as a principle which upgraded former administrative delimitations, established during the colonial period, to international frontiers, is therefore a principle of a general kind which is logically connected with this form of decolonization wherever it occurs." "55 Judge ad hoc Abi-Saab insisted, in a separate opinion, that "there can therefore be no question of even circuitously finding in contemporary international law any retroactive legitimation whatever of colonialism as an institution."

It is a good proposal, but it is perched precariously on a very fine line, for this particular boundary doctrine can, if applied indiscriminately, perpetuate the effects of the quintessential colonial technique of ignoring indigenous habitation patterns and depriving indigenous peoples of their rights. The problem for decision makers is to develop a more nuanced policy that takes account of the manifest need for interstate boundary stabilization and the international protection of the territorial rights of indigenous peoples. ${ }^{57}$ The policy of stabilizing interstate borders at the approach of the twenty-first century may have much to recommend it, but surely that policy can be effected in ways that do not compromise indigenous rights.

As a third step, the Court should view the absence of standing of indigenous peoples as its problem and should try to develop functional equivalents for appearance by indigenous peoples. Contemporary international relations theory acknowledges that many nonstate actors are important participants in the international process. But the essentially state-based structure of formal international law and the rules of standing in international adjudication, which recognize only states, have acted to preclude international tribunals from acknowledging this fact.

There is no ombudsman for indigenous peoples, and it will not be easy to create an international functional equivalent for cases implicating their interests in which they are not or cannot be present. The Inter-American Court of Human Rights, to its credit, allows forms of amicus representation in cases before it, ${ }^{58}$ but that Court does not hear boundary or territorial disputes. The International Court has resisted such an institu-

\footnotetext{
${ }^{52}$ Resolution on the Intangibility of Frontiers, OAU Doc. AGH/Res. 16(I) (1964), quoted in id. at 564, reprinted in Documents of THE ORGanization OF AfRICAN UNITY 49 (Gino J. Naldi ed., 1992).

${ }^{35}$ Frontier Dispute, 1986 ICJ REP. at 557.

55 Id. at 566 .

${ }^{54} I d$. at 565 .

${ }^{56}$ Id. at 659 (Abi-Saab, J., sep. op.).

${ }^{57}$ For one statement of the emerging norm of international law governing indigenous peoples, see Raidza Torres, The Rights of Indigenous Populations: The Emerging International Norm, 16 YALE J. INT'L L. 127, 14574 (1991).

${ }^{58}$ Rules of Procedure of the Inter-American Court of Human Rights, Art. 34(1), in OrGanIZATION OF AMerican States, HaNdboOK of Existing Rules Pertaining to Human Rights IN THE INTER-AMERICAN SYSTEM, OEA/Ser.L/V/II.65, doc. 6, at 167 (1985) ("The Court may, at the request of a party or the delegates of the Commission, or motu proprio, decide to hear as a witness, expert, or in any other capacity, any person whose testimony or statements seem likely to assist it in carrying out its functions."); see also Dinah Shelton, The Participation of Nongovernmental Organizations in International Judicial Proceedings, 88 AJIL 611, 638-40 (1994) (tracing participation by nongovernmental organizations as amici curiae in briefs and oral proceedings before Inter-American Court of Human Rights). The intervention of Nicaragua in Gulf of Fonstca marked the first time the ICJ or the Permanent Court of International Justice permitted a third party to intervene under Article 62 of the Statute. 1992 ICJ REP., para. 42 1, 1992 WL 457492, at*458.
} 
tion..$^{59}$ The Court could, however, make the rights of indigenous peoples an issue in cases concerning territory by posing questions from the bench and asking for specific evidence with regard to them.

V.

Modern computer software programs can make appropriate changes through an entire universe with a single keystroke. Would that the corpus of international law could be updated as quickly and efficiently. Changes in international law, alas, are registered much more slowly, deliberately and unevenly. Even though the international human rights program has recognized the peed to protect indigenous peoples and certain critical indigenous rights have been established in a number of authoritative documents, adjustments taking account of these changes have not been carried over into other parts of international law. No automatic program can accomplish this. In every case in which an indigenous claim could have been lodged but for the standing impediment, the judges involved should raise the issue, so that the international corpus juris will advance, case by case, until the international legal system provides justice for all.

W. MiCHAEI. REISMAN*

\footnotetext{
${ }^{59}$ For an analysis of participation by international organizations, nongovernmental organizations, and individuals as amici curiae before the International Court of Justice, see Shelton, supra note 58 , at 619-28. Shelton argues that the Court may accept submissions from nongovernmental organizations in advisory, but not contentious, procéedings. Id. at 628 . To date, the Court has invited only one subinission from a nongovernmental organization: a statement in the 1950 International Status of South-West Africa proceedings, 1950 ICJ REP. 128 (Advisory Opinion of July 11), from an international human rights group, which the Court rejected on technical grounds. Shelton, supra, at 623-24. In 1970 the present author sought permission to file "some form of amicus curiae brief" with the Court. Professor Reisman to the Registrar, 1970 ICJ Pleadings (2 Namibia) 636-37 (Sept. 10, 1970). The Registry denied the request on the grounds that Article 66 , paragraph 2 of the Statute of the Court limited the Court to receiving information exclusively from states and public international organizations. Registrar to Professor Reisman, id. at 638-39 (Nov. 6, 1970).

* The author acknowledges the research assistance of Douglas L. Stevick, J.D. 1996, Yale Law School.
} 